\title{
The Upper Orange River Water Resources Affected by Human Interventions and Climate Change
}

\section{Mahasa Pululu $\mathbf{S}^{1 *}$, Palamuleni Lobina $\mathbf{G}^{2}$ and Ruhiiga Tabukeli $\mathbf{M}^{2}$}

${ }^{1}$ Department of Geography, Faculty of Natural and Agricultural Sciences, Qwaqwa Campus, University of the Free State, Phuthaditjhaba, South Africa ${ }^{2}$ Department of Geography \& Environmental Sciences, School of Environmental and Health Sciences, Mafikeng Campus, North West University, Mmabatho, South Africa

\begin{abstract}
The major problem in the study area is the unlawful water abstractions for irrigation use. In South Africa, indications show that about 240 million $\mathrm{m}^{3} / \mathrm{a}$ of illegal water use is due to unauthorised withdrawals or violations of water use licenses. The status of water use for irrigation in the Orange-Senqu Basin also shows that insufficient information exists such that work needs to be done to understand the potential for increased efficiency of water use, taking into account issues pertaining to crop type, soil type and technological options. Studies like this one could also shed light on the potential impact of climate change on water use in the basin as this area may well experience significant impacts from rising temperatures and changing rainfall patterns. The processes of validation and verification will determine the extent of existing lawful water use. The use of remote sensing techniques (satellite, aerial photographs, etc.) could be employed to determine if the volume of water use registered by irrigators is accurate, i.e. valid and that the volume of water use registered is lawful (verification). Currently, ecological requirements for the river mouth are met through releases from Vanderkloof Dam and amount to just 290 million $\mathrm{m}^{3} / \mathrm{a}$. However several recent studies including the Gesellschaft für International Zusammenarbeit - Integrated Water Resources Management (GIZ - IWRM) study highlight that this is based on a fairly outdated methodology. The more recent Lower Orange Management study found a high level estimate of ecological requirements to be in order of 1062 million $\mathrm{m}^{3} / \mathrm{a}$.
\end{abstract}

Keywords: Water demand; Water allocation; Water user association; Irrigation board; Orange river; Lesotho; South Africa

\section{Introduction}

This paper focuses on the different water users in the study area. According to Meyer [1], South Africa uses $97 \%$ total water withdrawal from the Orange River thus making it the largest water user. It is further mentioned that although Lesotho contributes to over $40 \%$ of the stream flow, it only uses $1 \%$ of the water resources, further downriver outside the study area Botswana accounts for less than $1 \%$, and Namibia uses about $2 \%$. Agriculture is the main activity in the basin and this account for $61 \%$ of water demand in the area such that agriculture-inclined employment accounts for more than $50 \%$ of the basin's population. Most agricultural activities are along the fertile strips next to the river, but most of the commercial agriculture is artificially irrigated, using water both from the river and from groundwater due to the region's aridity [2-6]. Large parts of the basin are used for commercial rain-fed agriculture (e.g. for maize and wheat production)[7]. Other users in the area are large urban residential centres and industries in the Greater Bloemfontein area and to a limited smaller extent the rural centres scattered across the study area. This Caledon-Modder System supplies water to the Mangaung-Bloemfontein urban cluster (largest urban centre in the study area) [8].

\section{Geographical overview}

The Upper Orange Water Management Agency (WMA) covers 103 $671 \mathrm{~km}^{2}$ and is part of the Orange River watercourse. Lesotho has been included in the study area and covers $30492 \mathrm{~km}^{2}$. The total area is 134 $163 \mathrm{~km}^{2}$ as shown in Figure 1. This area lies between Latitudes $\left(28^{\circ} 0^{\prime} 0^{\prime \prime}\right.$ and $\left.32^{\circ} 0^{\prime} 0^{\prime \prime} \mathrm{S}\right)$ and Longitudes $\left(24^{\circ} 0^{\prime} 0^{\prime \prime}\right.$ and $\left.30^{\circ} 0^{\prime} 0^{\prime \prime} \mathrm{E}\right)$. The Orange River, (called the Senqu River in Lesotho), originates in Lesotho Maluti Mountains, close to the Lesotho's highest peak, Thabana Ntlenyana at $3.482 \mathrm{~m}$ above sea level. If there were no developments of any nature in the river basin, the average natural run-off would be more than 12000 million $\mathrm{m}^{3} / \mathrm{a}$, representing the average river flow that would be evidenced. It now happens that less than half of the natural runoff reaches the river mouth at Alexander Bay due to high levels of developments in the basin $[9,10]$.

\section{Lesotho}

Table 1 shows Lesotho farmers' categories and crops produced.

\section{South Africa}

On a national level in South Africa, estimated volume of water per sector is summarised below and this information from Water Authorization and Registration Management System (WARMS) [11].

\begin{tabular}{|l|l|}
\hline \multicolumn{2}{|l|}{ Proportion of water use per main economic sector } \\
\hline Agriculture / Irrigation & $60 \%$ \\
\hline Municipal /Domestic & $27 \%$ (i.e. 24\% Urban, 3\% Rural) \\
\hline Industrial & $\pm 3 \%$ (If not part of Urban Domestic) \\
\hline Hydro-electricity generation & $2 \%$ \\
\hline Mining and associated activities & $\pm 2 \%$ \\
\hline Livestock and Nature conservation & $2.5 \%$ \\
\hline Afforestation & $3 \%$ \\
\hline
\end{tabular}

*Corresponding author: Mahasa Pululu Sexton, Department of Geography, Faculty of Natural and Agricultural Sciences, Qwaqwa Campus, University of the Free State Private Bag X13, PHUTHADITJHABA 9866, South Africa, Tel: (+27) 58718 5036; Fax: (+27) 58718 5055; E-mail: mahasapululusexton@gmail.com

Received August 21, 2015; Accepted September 18, 2015; Published September 27, 2015

Citation: Mahasa Pululu S, Palamuleni Lobina G, Ruhiiga Tabukeli M (2015) The Upper Orange River Water Resources Affected by Human Interventions and Climate Change. Hydrol Current Res 6: 212. doi:10.4172/2157-7587.1000212

Copyright: ( 2015 Mahasa $P$, et al. This is an open-access article distributed under the terms of the Creative Commons Attribution License, which permits unrestricted use, distribution, and reproduction in any medium, provided the original author and source are credited. 
Citation: Mahasa Pululu S, Palamuleni Lobina G, Ruhiiga Tabukeli M (2015) The Upper Orange River Water Resources Affected by Human Interventions and Climate Change. Hydrol Current Res 6: 212. doi:10.4172/2157-7587.1000212

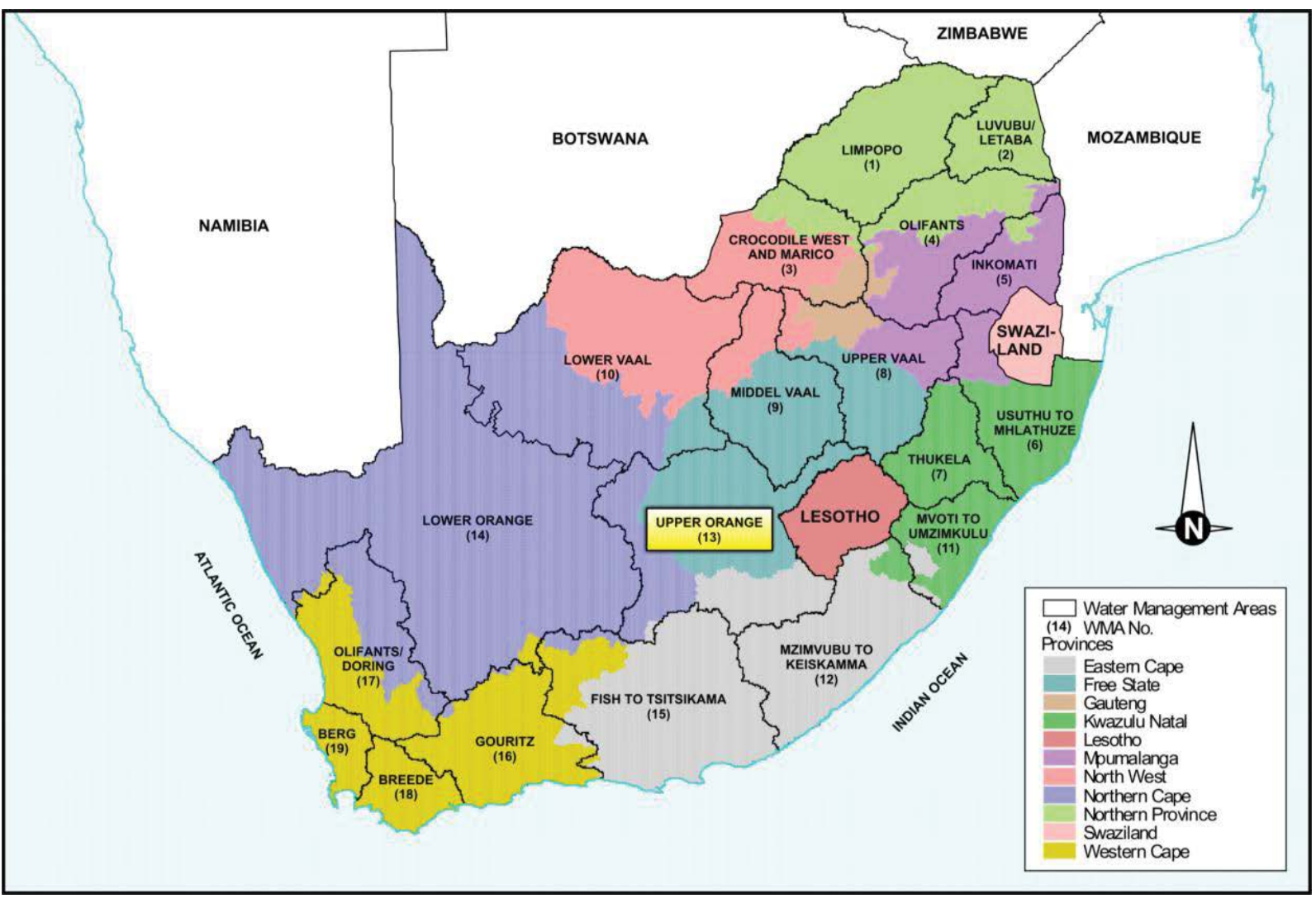

Figure 1: Location of Upper Orange River (DWAF 2004: 1-1)

\begin{tabular}{|c|c|c|c|}
\hline Type of Farmer & Irrigation System & Crops & $\begin{array}{l}\text { Size of Farm } \\
\text { (ha) }\end{array}$ \\
\hline \multirow[b]{2}{*}{ Subsistence Farmer } & None & $\begin{array}{l}\text { Maize, sorghum, } \\
\text { beans }\end{array}$ & $0.1-0.2$ \\
\hline & None & $\begin{array}{c}\text { Cereals, maize, } \\
\begin{array}{c}\text { sorghum, legumes, } \\
\text { potatoes }\end{array}\end{array}$ & $>0.2-1$ \\
\hline \multirow[t]{2}{*}{$\begin{array}{l}\text { Micro-irrigating } \\
\text { Farmer }\end{array}$} & $\begin{array}{l}\text { Watering can, hose } \\
\text { pipe/low pressure } \\
\text { sprinklers }\end{array}$ & $\begin{array}{l}\text { Vegetables, fruit } \\
\text { trees }\end{array}$ & $\begin{array}{c}0.025 \\
\text { (home } \\
\text { garden) }\end{array}$ \\
\hline & Gravity-fed irrigation & $\begin{array}{l}\text { Vegetables, fruit } \\
\text { trees }\end{array}$ & $0.1-0.5$ \\
\hline $\begin{array}{c}\text { Small-scale } \\
\text { semi-commercial } \\
\text { Farmer }\end{array}$ & $\begin{array}{l}\text { High-pressure } \\
\text { irrigation } \\
\text { system }\end{array}$ & $\begin{array}{l}\text { Vegetables, } \\
\text { fodder }\end{array}$ & $1-4$ \\
\hline $\begin{array}{c}\text { Medium-scale } \\
\text { commercial Farmer }\end{array}$ & $\begin{array}{c}\text { High pressure system } \\
\text { with } \\
\text { travelling guns }\end{array}$ & Vegetables & $10-20$ \\
\hline
\end{tabular}

Table 1: Lesotho farmers' categories and crops produced (ORASECOM 2011: 29).

Three things are worth-noting about the various user sectors above:

- Ecological Reserve (environmental-in-stream flow requirements). This water is not consumed.

- Alien vegetation has not been included above though provision of water for its existence should be allowed for.

- Hydropower. This water is not consumed apart from losses. It should be noted that hydropower is a secondary determinant of the weekly releases from Gariep and Vanderkloof Dams, irrigation requirements are the primary concern.

\section{Irrigation within the study area}

In South Africa the irrigation schemes are categorised as Government Water Schemes (GWS), Irrigation Boards (IBs) or Water User Associations (WUAs) [12]. From the Lesotho border to the Orange River delta, the Orange River is divided into 22 River Reaches to cater for irrigation. Irrigation is only facilitated from canal infrastructure that runs asymptotic the river or as direct abstraction from the river. Irrigation mostly occurs on commercial farms with freehold tenure on farming units that are 50 ha on average. However, numerous farms have acquired larger irrigated areas when irrigation units were consolidated under one owner so as to improve or maintain financial viability of irrigated farming. There is also another initiative from Government aimed at introducing and developing resource poor farmers on smallholder irrigation schemes [12]. Calibrated sluice gates facilitate the distribution to irrigation water to the farmers within schemes that are in close proximity to the river, while in some schemes located further afield or more centrally in the basin inline flow meters with telemetry are used. The irrigation infrastructure that distributes water and especially the lined open canals are old warranting widespread rehabilitation as an immediate requirement. Approximately 85000 ha of irrigation is done in these schemes. Specific challenges pertinent to this area warranted the need to identify water users in the study area; and to identify actual allocation of water needs by Department of Water Affairs (DWA)-Republic of South Africa (RSA), Lesotho Highlands Development Authority (LHDA) and Department of Water Affairs (DWA)-Lesotho. 


\section{Methodology}

\section{Sampling procedure}

One expert from each water department or entity was interviewed. The interviews were conducted on a four tier setting namely national, water management agency (WMA) or provincial, district and local municipal levels. In total on the South African side, interviews conducted were two at national, three at WMA level, four at district and twelve at local municipality levels. On the Lesotho side, interviews conducted were two at national, one (i.e. Water and Sewerage Authority-WASA) at department level and three at local levels. The sampling strategy and network was designed to cover wide range of determining factors (i.e. water allocation needs, number of licenses issued, etc.) at the key sites, which reasonably represented the whole study area. It involved retrieving information from the national, provincial, municipal and various users' inventories in the area.

\section{Data collection}

Primary data was collected through field surveys. Two secondary data, namely, archival data was made available in digital form from the Department of Water Affairs, Department of Environmental Affairs (DEA) and various stakeholders dealing with water management issues. Similar secondary data was obtained from the Lesotho Highlands Development Authority (LHDA) of the Lesotho Highlands Water Project (LHWP), Ministry of Water, Energy and Mining (WEMMIN), (Water and Sewerage Authority-WASA) and the Maseru Municipal Council. In order to achieve these objectives, structured interview was conducted amongst selected transnational departments, namely DWAF-RSA, Lesotho Highlands Development Authority (LHDA) and Department of Water Affairs (DWA - Lesotho) in order to identify the various users in the study area. The water users were determined based on data availability and their relative role in local economy (i.e. relative to agriculture, industrialisation, residential consumption and tourism). Experts from three WMAs (namely Bloemwater and Sedibeng Water Republic of South Africa (RSA) side) and WASA (-on the Lesotho side) was used for obtaining this information.

\section{Results}

In total the area has seven water user associations and/or IBs. The last two are outside the study area but are supplied from the area through Inter-basin Transfers (IBTs) in the Orange River upper reaches of the area and "which is notably much interconnected" [13]. According to ORASECOM [12], "it is a tremendously integrated water resource system that is highly complex with numerous large intra-and inter-basin water transfers. In the world the Orange River basin is the most complicated and integrated river basins and is operated using highly sophisticated system models which have been developed over a period of more than 25 years."

- Kalkfontein water user association

- $\quad$ Orange Riet water user association

- $\quad$ Lower Modder River water user association

- Orange Vaal water user association

- Christiana water user association (Bloemhof Dam)

- Boegoeberg water user association

- Vaalharts water user association

- $\quad$ Sand Vet water user association

\section{Characteristics of individual water user association}

Individual characteristics of water user associations are discussed in this section. The last two water user associations are not in the study area but due to the complex inter-transfers between basin and subdivisions it could be arguably correct that they are supported from the Orange River due to an upstream transfer into the Ash River and finally into the Liebenbergsvlei River.

\section{Kalkfontein water user association}

Originating as a GWS the Kalkfontein scheme, in 1994 it became an IB. In 1998 in terms of the new Water Act, it happens to be the first IB to be transformed to a water user association. The Kalkfontein Dam receives its water from three basins, The Riet River, Kromellenboogspruit and Tierpoort Dam catchments. The Kalkfontein Dam receives its water directly from the Riet River catchment which generates a runoff of 83.96 million $\mathrm{m}^{3} / \mathrm{a}$, provides $49.97 \mathrm{~km}^{2}$ of water in support of irrigation purposes with 31.34 million $\mathrm{m}^{3}$ remaining in the reservoirs of the catchment. This dam is also receives water from the Kromellenboogspruit catchment (i.e. runoff of 101.89 million $\mathrm{m}^{3} / \mathrm{a}$, $20.71 \mathrm{~km}^{2}$ in support of irrigation and 26.58 million $\mathrm{m}^{3}$ remain in the reservoirs of the catchment) and the Tierpoort catchment (i.e. runoff of 23.23 million $\mathrm{m}^{3} / \mathrm{a}, 23.35 \mathrm{~km}^{2}$ in support of irrigation and 17.25 million $\mathrm{m}^{3}$ remain in the reservoirs of the catchment) [14-16].

Irrigators are supplied with water by lined canals on either sides of the Riet River downstream. Other irrigators pump directly from the Riet River. According to ORASECOM [12], initially 3526 ha was under irrigation, with canals supplying water for 3046 ha while pumping direct from the river supplies 480 ha. The total serviced area of 3502.9 ha now remain after pumping from the river was reduced to 456.9 ha. Originally the intention was that canals should provide water for flood irrigation but now about $10 \%$ is flood irrigated while irrigation via centre pivots is now $90 \%$. A total of 120 irrigators are supplied from the Kalkfontein water user association.

Measurement of all water for irrigation use is carried out including those that use telemetry to determine water demand. Measurement of water consumed by canal users is done using calibrated sluices. Line water meters are used for irrigators that extract directly from the river. On average maize occupies $60 \%$ of the area is planted on a two year rotational basis with wheat and three other crops. Lucerne is planted on $20 \%$ of the land when a variety of other crops occupy the remaining $20 \%$ [12].

Together with Kalkfontein water user association which supplies irrigators, other users in the area include urban areas of Koffiefontein, Jacobsdal, Jagersfontein and Fauresmith. Water is also supplied to two De Beers mines at Jagersfontein and Koffiefontein [14].

Water allocated is $11000 \mathrm{~m}^{3} / \mathrm{ha} / \mathrm{yr}$. However billing on users is done on the actual use on a volume basis.

It is a common phenomenon for water to be short supply in this WUA. On the basis of the Kalkfontein Dam, farmers may receive as little as $15 \%$ of their allocation in some years. Again there is a noticeable deterioration of water quality because the Riet River flows rarely. Farmers in this part of the study area are highly conscious of Water Conservation and Water Demand Management (WC/WDM) because of regular shortages of water [12].

\section{Orange riet water user association}

Of all of the schemes, formed in 2000 this happens to be the most 
complicated. It is the result of the transformation of the Riet River GWS, formerly consisting of the Riet River Settlement, the Ritchie Irrigation Area and Scholzberg Irrigation Area, and the Lower Riet IB. Numerous lined canals serve the scheme while other irrigators pump directly from the Riet River. Because it was common for water to be in short supply in the Riet River, this led to the construction of the Orange Riet Transfer Scheme so as to convey water from the Vanderkloof Dam, on the Orange River, to service these areas. Water from the Orange River is pumped to a point high enough so that it could move under the influence of gravity via a canal to the serviced area. Irrigators along this transfer canal draw water directly from the canal. Initially the 16903 ha were under irrigation but the area has been expanded to 17050 ha after allocation purchases from the Eastern Cape. The canals were initially meant for flood irrigation purposes. At present about $90 \%$ of the area is under irrigation through centre pivots while $9 \%$ still maintains flood irrigation and the remaining $1 \%$ using other systems. In total 190 irrigators are supplied from the Orange Riet water user association.

All users are measured by either in-line water meters or calibrated sluice. Telemetry is connected to a central $24 \mathrm{hr}$ control station and has to monitor all measuring stations thus making water to be available only on demand. The level of expertise shown by the Orange Riet water user association in South Africa for water measurement and use is the best so far [12].

Wheat (37\%) and lucerne (26\%) are the main crops. The remaining $37 \%$ caters for like maize, potato, barley, oats, groundnut, grapes and other crops. Allocations are done on a volume basis such that 11000 $\mathrm{m}^{3} / \mathrm{ha} / \mathrm{yr}$ is allocated. However billing of actual use on users is on volume basis. Similar to the Kalkfontein water user association's case, the water in the Riet River does not always flow and there is drastic deterioration of water quality further down the river.

A virtual water bank is operated by the Orange Riet water user association. Subject to decreased use irrigators may trade their water allocations or hand the water back to the water user association who may sell the water to willing buyers at a premium [12].

\section{Lower modder river water user association}

In 2010 the Lower Modder River water user association was established and it incorporated the former Modder River GWS. Because it is next to the well-managed Orange Riet water user association, the Lower Modder River Board decided to "piggyback" on the expertise of the Orange Riet water user association and which also manages the Lower Modder River water user association. These two water user associations utilise the services of a common CEO [12].

The water user association obtains its water from the Krugersdrift Dam on the Modder River and irrigators abstract directly from the Modder River to provide for irrigation of 3526 ha. According to ORASECOM [12]. Measurement of water uses in-line water meters fitted with telemetry and about $90 \%$ of the irrigators are supplied. In 2011 plans were put in place to measure the remaining 10\%. The annual allocations and crop mix are similar to those of the Orange Riet water user association. The water user association is managed in a similar manner as the Orange Riet water user association by using the same operating procedures and personnel.

\section{Orange vaal water user association}

In 2007 when the Orange Vaal IB's were converted to a water user association, the Orange Vaal water user association was formed. According to ORASECOM [12] initially the total irrigated area was
8113 ha and was increased to 11058 ha when purchases of water allocations from outside the scheme were made.

The scheme is situated at the confluence of the Orange and Vaal Rivers. Initially its water was extracted from the Douglas Weir situated on the Vaal River. It was deemed necessary to construct a transfer scheme from the Orange River to the Douglas Weir due to an increase in water use upstream in the Vaal River basin. This transfer scheme, known as the Orange Vaal Transfer Scheme, has an installed pumping system to covey water into the Bosman Canal flowing into the Douglas Weir in another catchment area. The Vanderkloof Dam supplies the entire scheme's water allocation via the Orange Vaal Transfer Scheme. Under is irrigation about $90 \%$ of the area, which pumps directly from the Douglas Weir, the Bosman Canal or the Orange River downstream of the Douglas Weir. About $10 \%$ of the area is serviced by water from two canals, the Atherton and the Buckland Canals. Originally these canals were intended for flood irrigation supply. However $90 \%$ irrigation is done through centre pivots, $7 \%$ by other systems and only $3 \%$ still maintains flood irrigation [12]. It is further mentioned that 180 irrigators are supplied by the Orange Vaal water user association.

Measurement using calibrated sluices is used to determine allocations made to canal users. Pertaining to water use by irrigators, measurement is not done physically but it is calculated on a preseason basis. About $90 \%$ is under irrigation through centre pivots that are known for their application rates for each area known. Since operational plans of each irrigator relating to planting have to be communicated to the water user association, then the water user association determines the allocation. It is calculated as a product of average weekly evaporation rates for the past five years multiplied by a crop factor to determine the amount of water required for the crop and the area. In consultation with the irrigator the areas are then adjusted until the annual requirement is equal to the irrigator's allocation and both parties are in agreement. Planting is only limited to areas that have been agreed upon by the irrigator and the water user association usually validation of this information follows afterwards.

Maize is planted to about 5000 ha (45\%) and this in rotation with wheat and three other crops that are grown every two years. Lucerne occupies 2000 ha (18\%) while cotton occupies 2000 ha (18\%). The remaining area (19\%) may be used for a wide variety of other crops [12].

Users are charged on a volume per area per year (i.e. $\mathrm{m}^{3} / \mathrm{ha} /$ annum) basis. Originally allocations were about $9140 \mathrm{~m}^{3} / \mathrm{ha} / \mathrm{yr}$ but have increased due to purchased allocations to $10000 \mathrm{~m}^{3} / \mathrm{ha} / \mathrm{yr}$ [12]. A result of poor quality water from the Vaal River is a major water quality problem to the Orange Vaal water user association. Industrial pollution and acid mine drainage from the Vaal River catchment, and nutrient rich sub-surface drainage water from the upstream Vaalharts scheme results in as high as 861 of total dissolved solids (TDS), while an alarmingly high value of 1500 TDS is produced by the drainage water from the Orange Riet and Kalkfontein schemes upstream on the Riet River. In contrast the water from the Orange River has a TDS of only 145. Water that emanates from all three sources is deposited in the Douglas Weir [12]. It is further alluded that research has shown that as a result of different densities the good and poor quality water do not mix but remain in envelops which cause problems for irrigators when the envelop of poor quality water pass the extraction points [17].

\section{Christiana water user association (Bloemhof Dam)}

Submission of a proposal for establishing a water user association 
has been delayed until so far. This is because a consensus could not be reached on registration of water use over such area and also because questions arose as how registered volumes of irrigation water could be utilised without exceeding the permit abstraction flow-rate [12].

\section{Boegoeberg water user association}

Established in 2003 the Boegoeberg water user association came into being when the Boegoeberg GWS, the Gariep IB, the Northern Orange IB, a portion of the Middle Orange Irrigation Area, and the Karos Geelkoppan Water Board amalgamated. Under irrigation in the scheme now the total area is 9198 ha. In 1931 the Boegoeberg GWS was formed [12]. Field observations revealed similarities with other schemes in the area in that lined canal on one or both sides of the Orange River and do so downriver. Most farmers' irrigation activities are fed from canals while some farmers pump directly from the rivers. From the Boegoeberg water user association is supplied 306 irrigators also nine livestock farmers for domestic and animal purposes with water. Livestock farming occupies 60000 ha of the area in this scheme [12]. The initial design of the scheme was to be flood irrigated such that even now flood irrigation accounts for $90 \%$ of the area while irrigation with micro and drip irrigation is done on the remaining $10 \%$. Laser levelling has been done on $30 \%$ of the flood irrigated area to improve on irrigation efficiency. There are 306 irrigators in the scheme. Calibrated sluices are used to measure consumption by canal users (i.e. 297 users) and only 9 river users are not measured. Grapes account for $80 \%$, maize and lucerne $(10 \%)$, with other crops such as peas, wheat, cotton and pecan accounting for $10 \%$ of the area [12].

While irrigation water is rarely in short supply, users are billed on a volume/area/annum basis and presently the allocation is 15000 $\mathrm{m}^{3} / \mathrm{ha} / \mathrm{yr}$ for users on the Boegoeberg, Gariep and Northern Orange portions while the Middle Orange portion is allocated $10000 \mathrm{~m}^{3} / \mathrm{ha} / \mathrm{yr}$. The infrastructure is very old and the entire scheme needs immediate rehabilitation. Consequently high losses of water are experienced.

The operating philosophy is that the water user association has preserved the natural setting in terms of flow-rate by constructing a divergence of discharge and retaining losses as if the water is still in the river-course.

\section{Vaalharts water user association}

In 2001 the Vaalharts water user association was established when the Vaalharts GWS and the Harts GWS were amalgamated. This WUA receives irrigation water from the $\mathrm{KB}$ canals and the Taung Irrigation Scheme. The Bloemhof Dam on the Vaal River is the main source of supply and with some water supplied from the Spitskop Dam on the Harts River. The Vaalharts Weir collects water released from the Bloemhof Dam and then distributes it via lined canals to the Vaalharts, Taung and KB canal areas. Water from the Spitskop Dam is distributed via a canal to users downstream of the dam. Certain users also pump directly from the Vaal and Harts rivers. The Vaalharts water user association serves 900 users on a total area of 35700 ha. According to ORASECOM [12], initially it was designed as flood irrigation scheme with $40 \%$ still remains under flood irrigation, $40 \%$ is under irrigation by centre pivot and the remainder $(20 \%)$ uses micro and drip irrigation systems. Water released to irrigators is measured using calibrated sluices except for Taung which is not measured at all. Maize, wheat, vegetables, pecans, lucerne, groundnuts, citrus, cotton, olives and grapes are crops grown in the water user association. Billing on irrigators is done on a cubic meter per hectare basis. ORASECOM [12] mentioned that the Vaalharts and KB canals areas jointly obtain
$9140 \mathrm{~m}^{3} / \mathrm{ha} / \mathrm{a}$, Taung $8470 \mathrm{~m}^{3} / \mathrm{ha} / \mathrm{a}$ and the Harts area $7700 \mathrm{~m}^{3} / \mathrm{ha} / \mathrm{a}$. Infrastructure in the water user association is very old (i.e. $>80$ years) requiring major investment for rehabilitation.

Acid drainage from the Gauteng area causes the water quality from the Vaal River to deteriorate rapidly. High nutrients in the Vaal River lead to excess algae and water hyacinth growth which often blocks canals and structures used for measuring water use. Salinity in the Vaalharts scheme is also a problem. Consequently installations of sub-surface drainage had to be done on large portions of the scheme. Nutrient rich sub-surface drainage water from Vaalharts is collected in the Spitskop Dam resulting in water quality problems for users from this dam [18].

In 2014, there was a massive project aimed at the development of a joint business case by DWA, Vaalharts Water User Association, Department of Agriculture and Rural Development, 7 municipalities served by the scheme, National Planning Commission and Northern Cape and province and interested private sector.

\section{Sand vet water user association}

In 2007 the Sand Vet water user association came into being when two GWS amalgamated. This occurred between the Sand Vet GWS (i.e. supplied from the Allemanskraal Dam on the Sand River) and the Vet River GWS (i.e. supplied from the Erfenis Dam on the Vet River). Raw water for irrigation purposes is supplied to more than 700 privately owned and government owned settlement properties by means of the Allemanskraal Dam and the Erfenis Dam with a $651.84 \mathrm{~km}$ long system of channels and drains[19]. An area of 12317 ha is under irrigation consisting of 7162 ha on the Vet River and 5155 ha on the Sand River. Both schemes comprise of a lined canals on one or both sides of the river tracking the river course. The majority are supplied from these canals while some farmers pump directly from the rivers. In the Vet scheme 301 irrigators are supplied and 234 in the Sand scheme giving 535 irrigators in all.

Initially the design of the scheme was to be flood irrigated and only about $1 \%$ maintains the status quo. Irrigation by centre pivots accounts for $90 \%$ and the remaining $9 \%$ is under micro and drip irrigation [18]. Canal users are supplied with irrigation water by means of calibrated sluices while river users are supplied by means of in-line water meters.

The prominent crops grown are maize and wheat with some potatoes and groundnuts and also sunflower, oats, lucerne, onions and vegetables are cultivated under irrigation to some extent. DWA [19] also mention that the Sand-Vet also supplies raw water to be purified for commercial and household use to Theunissen, Bultfontein, Brandfort and Virginia as well as Harmony Mine, Correctional Services at Virginia and the Agricultural experimental farm. The annual operating cost for the Sand-Vet Water Scheme is approximately R 11 million. The scheme suffers from regular water shortages and users seldom receive their full annual allocation [12]. Users are charged on a cubic meter per hectare basis using calibrated sluice gates.

\section{Water Requirements}

At present most land use in the area is under natural vegetation with livestock farming (sheep, cattle, goats and some game) and conservation areas occupy large parts. Dry land cultivation to produce grains covers extensive areas and this lie in the north-eastern parts of the water management areas. Large irrigated areas for grain production, fodder crops, a wide variety grapes etc., have been developed along the main rivers, mostly downstream of dams. 
Irrigation accounts for representing $88 \%$ of the total gross water use of 1996 million $\mathrm{m}^{3}$ / and happens to be the dominant water use sector in the Orange River WMAs based on estimates for the year 2012. This amount excludes the transfers out of the WMAs. The urban, industrial, mining and rural sectors account only for $12 \%$ of the water use. Mainly from Lesotho and the Upper Orange WMA, transfers from the Orange River account for 2159 million m3/annum of water use. Expected future growth will mainly be as result of 12000 ha allocated to resource poor farmers and limited growth in urban/ industrial and mining sectors which will mainly be as result of developments in the Bloemfontein, Thaba 'Nchu area. The projected water use required for 2025 is 2134 million $\mathrm{m}^{3} / \mathrm{a}$ and this does not include the transfers. Until 2025 no new transfer schemes may be expected out of this area.

\section{Understanding growth in water requirements}

Usually the prediction of water requirements for purposes planning is based on the primary drivers of water demand, which are population growth and local economic growth. These two factors are intertwined to some extent, as economic growth may stimulate population growth as a result of migration from the rural areas or other urban area with a poor economy. There are also numerous other contributing factors that can impact future water requirements, and specifically for the Greater Bloemfontein area, these may include:

- Change in the level of service, as improvements in the water services, sanitation, and health awareness will most likely impact on future requirement scenarios. Typical initiatives in the study area include the eradication of water and sanitation backlogs linked to the UN Millennium Goals, as well as the delivery of houses to the poor to meet SA National target with regard to housing.

- The impact of HIV/AIDS is a significant factor, with the highest occurrence in the rural areas of South Africa.

- Improvement in water management in terms of water meter coverage, the extent and accuracy of meter reading and billing, and the effectiveness of credit control policies.

The historic growth in water requirement has not been consistent, and has fluctuated quite significantly. The water growth has included periods of negative or relatively flat growth possibly as a result of above average rainfall being experienced in these specific years.

Water use, when expressed on a per capita basis, is in the region of 200 litres per person per day. There are uncertainties, however, associated with the future population growth rate figures as described below.

\section{Population growth rates}

Population growth rates are based on the birth rate, mortality rate, and migration. The following sources and references were found which described the historic and possible future population growth rates.

- Information taken from the IDP report 2007/2008 for Mangaung Metropolitan Municipality indicated that the future population growth rate for Bloemfontein was $3.1 \%$ per annum. The growth in population between 1996 and 2001 based on 2001 Census figures for the Bloemfontein areas was estimated to be $3.1 \%$ per annum.

- A report entitled "Identification of Bulk Engineering Infrastructure in Support of Housing Development in Mangaung, Master-plan prepared for Mangaung Metropolitan Municipality determined that the anticipated population growth figures for Bloemfontein up to 2030 would be $1 \%$ per annum.
- Population projection scenarios were also developed for the All Towns study for Central Region (June 2009). This study proposed two alternative population growth scenarios, a High Population Growth Scenario and a Low Population Growth Scenario. The high population growth scenario translates to an aggregate population growth rate for Bloemfontein, Botshabelo and Thaba Nchu of $1 \%$ per annum, whilst the low population growth scenario translates to an aggregate population growth rate of $0 \%$ per annum.

- Migration is proportional to economic growth rate, implying a strong economic growth will result in "immigration" whereas a decline in economic growth will result in "emigration". Migration figures that could be relevant to the study area were sourced from Provincial trends as abstracted from the "2009 StatsSA Mid-Year Projections for the Orange Free State Province (2006 to 2011 Projection)". Migration affects the rural and smaller towns more significantly, as a result of people seeking economic and employment opportunities in the larger urban centres. Migration is assumed to vary between $0.00 \%$ and $0.25 \%$ for Bloemfontein and Botshabelo, assuming more people migrating to, and residing in these towns. For the smaller towns with less economic opportunity, the migration rates vary from between $-0.4 \%$ and $0.0 \%$. The assumption is that current residents could be leaving the smaller towns to reside and seek opportunities in the larger centres.

- The impact of HIV/AIDS is a significant factor when estimating population projections, and more specifically, its influence on the mortality rate. The impact of HIV/Aids relevant to the study area has been based on National statistics, where the highest occurrence is in the rural areas of South Africa. The mortality rate as a result of HIV/Aids has been assumed to be as high as $0.4 \%$ for the urban towns, and as high as $0.75 \%$ for the rural towns and villages.

\section{Economic growth rates}

The largest urban centre in the area is Bloemfontein, Botshabelo follows next and finally Thaba Nchu and most private and public investment occurred in these areas. The latest Integrated Development Plan (IDP) suggests that Bloemfontein shall still be the focus for future development as it is anticipated that Bloemfontein will be home to about $65 \%$ of the total population by 2016 .

The economy of the MMM plays a significant role in the Motheo District economy (92.5\%) as well as the Free State economy (25.5\%), but it is relatively small when compared to the national economy $(1,6 \%)$. Of importance is the relatively small share of the local agriculture, mining and manufacturing sectors compared to the province and the country. Mining's small share is understandable as the Mangaung area competes with the Goldfields area, which is very strong in mining; however the share of agriculture and manufacturing is disturbingly low. On the other hand, the tertiary sector of the local economy is very significant within the context of the province.

Approximately $87 \%$ of economic production in the MMM area occurs in Bloemfontein while only $7 \%$ and $6 \%$ respectively occur in Botshabelo and Thaba Nchu.

The overall annual economic growth rate for the Mangaung area was $3.59 \%$ between 2001 and 2004 and a significantly higher growth of 9.5\% occurred between 2004 and 2007. In Bloemfontein an economic growth rate between 2004 and 2007 of $9.86 \%$ was recorded compared with $8.55 \%$ in Botshabelo, while that of Thaba Nchu was considerably less at $5.08 \%$ per annum. This confirms the fact that the Bloemfontein economy is and will be increasing its proportional share of the economy. 
While community services contribute to over a third of Mangaung's economy, other prominent sectors include finance, retail and trade, transport, and manufacturing. The remaining sectors such as agriculture and mining are very small and make a minor contribution to the local economy. Community services contributes $35 \%$ to the city's economy, finance $18 \%$, trade $16 \%$, transport $13 \%$, manufacturing $8 \%$, agriculture $4 \%$, construction $3 \%$ and utilities $3 \%$.

Growth in the transport sector, given the strategic central location of Bloemfontein, is likely to be stimulated by increasing economic activity elsewhere in the country.

\section{Future water requirement scenarios}

The following assumptions were made for the development of the future water requirement scenarios from the Greater Bloemfontein Water Supply System.

- High Growth Water Requirement Scenario will take place on account of high population growth rate and high economic growth rates. Given the relatively low population projection growth rates and the contrasting relatively high historic growth in water requirements (the authorised billed and unbilled water consumption figures for the last 3 years have grown at a rate of $3 \%$ per annum) it was decided to use long term historical growth rate of $3 \%$ per annum as the basis for the high growth scenario.

- Low Growth Water Requirement Scenario will take place on account of low population growth and low economic growth. It was decided to base the low growth scenario on a growth in water requirement of $1 \%$ per annum.

The high and low water requirement projections have been projected from the 2009 base for the following reasons:

- There were significant summer rains in the 2011 and this may have resulted in a depressed demand.

- It is still too early to ascertain whether or not the drop in 2010 can be ascribed to structural reasons (e.g. improved metering, WC/WDM) or is as a result of climatic influences.

- It is conservative to plan from a higher base. As future years actual water requirements become known, the base from which the projections are made can always be changed.

\section{Important qualification}

It is important to note that the water requirement scenarios presented above were developed during a global economic crisis. The global recession and a slow recovery from this recession are likely to have significant implications for water requirement growth projections for the Greater Bloemfontein Water Supply System.

The implications of the recession for the strategy to meet future water requirements are as follows:

- The economic uncertainty increases uncertainty concerning the growth in water requirements.

- Water use must be continuously and carefully monitored;

- Future scenarios/projections need to be revised frequently, based on updated information;

- Planning to increase water availability needs to be as flexible as possible; and
- Interventions that are more flexible in terms of timing should be favoured, all other considerations being equal.

\section{Agricultural water requirements}

The only expected growth in irrigation requirements is the allocation of 12000 ha to resource poor farmers. The effect of the 12000 ha (4000 ha for the Upper Orange WMA, 4000 ha for the Lower Orange WMA, and 4000 ha for the Fish-Tsitsikama WMA) is estimated to be in the region of $114 \mathrm{~m}^{3} / \mathrm{a}$. The Implementation Strategy for the development of 3000 ha irrigation in the Free State Province indicates that there is \pm 200 ha available near Ficksburg (Caledon River) and \pm 2000 ha available next to the Orange- Riet Canal, which starts at the Vanderkloof Dam. The agricultural water requirement for the 200 ha near Ficksburg was taken into account in the determination of the available yield [20].

\section{Water balance reconciliation}

The Upper Orange WMA is a component of the extended Orange and Vaal River System. This has been the subject of various water balance and reconciliation studies. The latest water balance from the Orange River System indicated a surplus of 274 million $\mathrm{m}^{3} / \mathrm{a}$ for the year 2008 . Subsequent planning to supply water to emerging farmers and for the growth in water requirements in the Upper Orange, Lower Orange and the Fish to Tsitsikamma WMAs would reduce this surplus to only 40 million $\mathrm{m}^{3}$ by 2025 . Furthermore the proposed developments under Phase 2 of the Lesotho Highlands Water Project would reduce the yield of the Orange River downstream by approximately 283 million $\mathrm{m}^{3} / \mathrm{a}$ (proposed Polihali Dam and transfer). Based on a conceptual estimate of the mass balance across the Orange River system, it can be inferred that a system deficit of about 243 million $\mathrm{m}^{3} / \mathrm{a}$ could be expected by 2037. It can be concluded that there is currently surplus water available in the Orange River system (including the Caledon River) which can be allocated to the Greater Bloemfontein Area. Other water resource development options on the Orange River will only become feasible after the water requirements from the Vaal WMA have increased to such an extent that they reduce the availability of water in the Orange River, and a new supply intervention is implemented to augment the loss in yield [21,22].

The future Polihali Dam site is situated on the Senqu River approximately $1.5 \mathrm{~km}$ downstream of the confluence of the Senqu and Khubelu Rivers. Polihali Dam would increase the water delivered from Lesotho Highlands Water Project to the high value industries in the Vaal catchment, but would, in the long term, result in a reduction in the water available at downstream Gariep and Vanderkloof dams. It is envisaged that the Polihali Dam would reduce the yield of the Orange River downstream by approximately 283 million $\mathrm{m}^{3}$. This is based on the assumption that overall yield of the system increases by 182 million $\mathrm{m}^{3} / \mathrm{a}$ but an additional 465 million $\mathrm{m}^{3} / \mathrm{a}$ might be transferred to Gauteng, causing a shortfall of 283 million $\mathrm{m}^{3} / \mathrm{a}(46-182=283)$ [22]. Table 2 shows a mass water balance of the Upper Orange WMA.

The Upper Orange WMA has a large commitment to support the local water requirements and transfers to the Upper Vaal WMA, the Fish to Tsitsikama WMA, as well as release obligations to the Lower Orange WMA. A number of augmentation interventions have been identified to provide additional yield to the Orange River System to make up the envisaged shortfall caused by transfers from Polihali Dam to the Gauteng area. Some of the interventions identified include: using the lower level storage in Vanderkloof Dam; the construction of Bosberg/Boskraai Dams; and the raising of Gariep Dam. It is the 


\begin{tabular}{|c|c|c|}
\hline & Surplus Yield (million $\left.\mathrm{m}^{3}\right)-2004$ & Surplus Yield (million $\left.\mathrm{m}^{3}\right)-2012$ \\
\hline Year Surplus Yield & $333(2000)$ & $274(2008)$ \\
\hline Less Transfer to Gauteng from the Mohale Dam (impact on Orange River) & -175 & -175 \\
\hline Net Available Yield & 158 & 158 \\
\hline Less Allocation for Resource Poor Farmers & -114 & -144 \\
\hline Net current available yield for growth in urban water requirements & 44 & 44 \\
\hline $\begin{array}{l}\text { Less growth in urban, industrial and mining sectors in the Upper Orange WMA, the Lower Orange } \\
\text { and allocation for resource poor farmers of the Fish-Tsitsikama area (NWRS 2025) }\end{array}$ & -90 & -90 \\
\hline Net deficit in yield in 2025 & -46 & -40 \\
\hline Less Transfer to Gauteng from the Polihali Dam (impact on Orange River in 2053) & -283 & -283 \\
\hline Anticipated net yield (will be higher with additional growth in urban water requirements) & $-329(2053)$ & $-243(2037)$ \\
\hline
\end{tabular}

Table 2: Orange River Water Balance (DWA 2012e:19).

intention of the DWA to initiate a separate reconciliation strategy study on the Orange River System, which will draw on the information from the Greater Bloemfontein Reconciliation Strategy Study.

\section{The Greater bloemfontein area}

The anticipated surplus yield in the Orange River System (including the Caledon River) is approximately 44 million $\mathrm{m}^{3} / \mathrm{a}$. According to the Internal Strategic Perspective for the Upper Orange River WMA, this surplus is reserved for the growth in demands in the urban, industrial, and mining sectors in the Upper Orange WMA, the Lower Orange, and the Fish to Tsitsikama WMAs. It is not anticipated that there will be any further growth in agricultural water requirements in the Greater Bloemfontein Area (with the exception of the allocation made to the resource poor farmers) [23]. As the agricultural sector and urban sector in the Greater Bloemfontein Area and surrounds do not share any yield from a common surface water resource, it is possible to undertake a reconciliation of supply and requirement based on the current urban water requirements and available yield of the surface water schemes serving the Greater Bloemfontein area and surrounds.

Figure 2 illustrates the comparison of available surface water supply and current water requirements for the High and Low water requirement scenarios in the Greater Bloemfontein Area. The current water requirement (based on 2009 data) is approximately 83 million $\mathrm{m}^{3} / \mathrm{a}$ while the available supply is 84 million $\mathrm{m}^{3} / \mathrm{a}$ (Historical Firm Yield).

It appeared that the 2009 water requirement was in balance with available supply (historical firm yield) and any increase in use (as predicted by the high and low water requirement scenarios) would put the system at risk. The higher the growth in water requirements, the higher the risk would be. It is clear that measures to increase the surety of supply need to be implemented as soon as possible. This includes measures to increase the supply of water as well as WC/WDM measures to reduce the demand.

\section{Issues which could impact on the reconciliation of supply and requirement}

There are a number of issues which could impact on the reconciliation of supply and requirement in the longer term. These issues are listed below:

\section{- Effectiveness of WC/WDM;}

- Existing bulk water supply infrastructure capacity i.e. bulk water pipelines and water treatment works.

- Illegal use of water;

- Impact of HIV/Aids;
- Migration of people from the rural areas to the urban centres, particularly Bloemfontein;

- Sedimentation; and

- Surface and groundwater quality.

\section{Discussion}

There are tremendous differences in determining the users in the study area and equally so are methods of determining allocation schedules across the whole study area. This is because no pro-active water demand management is employed. One issue which came up repeatedly was the importance of measuring water usage at the farm and distributer level. This step is fundamental to successful implementation of a whole range of practices which can lead to improved water conservation and water demand. Directly linked to the issue of measurement is how water is paid for. Once paid for volumetrically, a whole range of incentives can be put in place to encourage farmers to use their allocations of water more efficiently. Another important factor was that although identification and description of best management practices can be done individually, concerted efforts through working together in a holistic approach to scheme and farm management could bring about the full realisation of benefits of each best management practice. Finally, and perhaps most importantly, within the South African context, there was generally agreement that the South African Water Act and its provisions for water user associations and water management plan provided an excellent framework for water conservation and water demand management to take place. The establishment of the irrigation database has shown that significant changes in irrigation practices are taking place and that additional areas are being put under irrigation.

\section{Conclusions}

A reduction in water consumption largely due to the presence of a virtual water bank was evident in the area resulting in greater accountability resulting from volumetric metered payment system. It was noted that increased level of awareness and expertise amongst irrigators tied to demonstration of best practices led to other water user associations improving their water use efficiency.

\section{Recommendations}

There should be accelerated and supported implementation of the South African Water Act and catchment management agencies and its provisions for water user associations. This framework provides valuable lessons which can be used even from the other basin states. It is a necessity to improve irrigation water measurement at both the distributor and irrigator level through encouragement and be mandatory as well. It is a further recommendation that investigating 
Citation: Mahasa Pululu S, Palamuleni Lobina G, Ruhiiga Tabukeli M (2015) The Upper Orange River Water Resources Affected by Human Interventions and Climate Change. Hydrol Current Res 6: 212. doi:10.4172/2157-7587.1000212

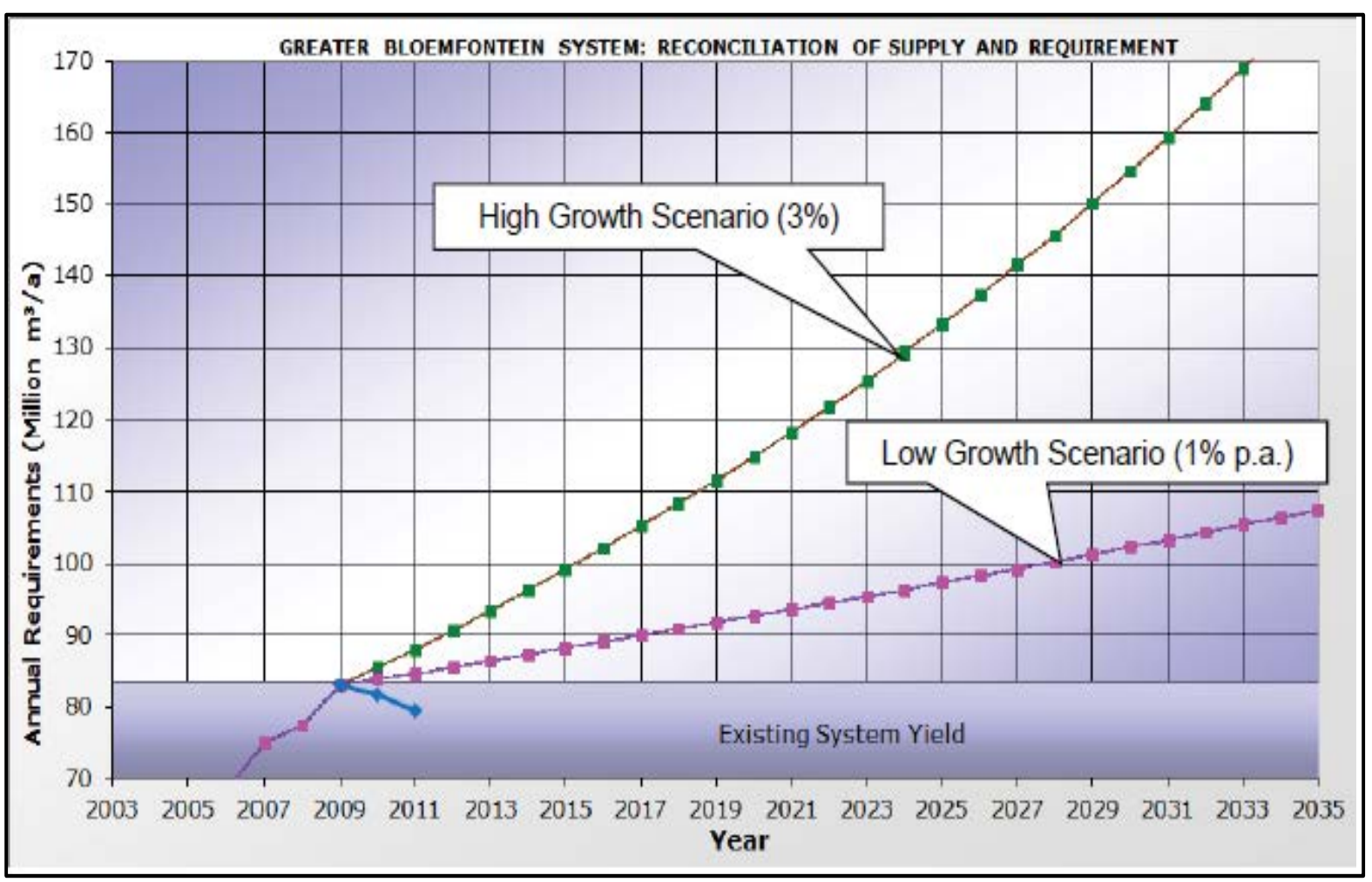

Figure 2: Surface Water Balance for Study Area (DWA 2012: 20).

the cost and extent of this requirement may be expedited and funding options determined.

Attempts have to be made to advocate for investigation of the possibility of offering assistance to Water User Associations so that they may establish appropriate GIS-type data-base of irrigated lands, irrigation, cropping patterns, requirements etc. (including the training of personnel) for the improvement of water management and water use. Data acquisition could be useful at the Water User Association level and lead to the improvement on estimating parameters related to irrigation in the catchment area.

Demonstrations of the best practices at site-locations (for both irrigators and suppliers of irrigation water) could enhance the dissemination of information on efficiency of these irrigation practices. It is another recommendation that the database of areas under irrigation is updated regularly on a yearly basis and that classification using the remote sensing tools is developed, complimented by GIS ground truth database of Water user associations such that wasteful water demands on the overall can curbed, or keeping growth rates at low levels could prove beneficial. During this process continued capacity-building should be advocated for.

\section{References}

1. Meyer C (2013) Integrated Water Resources Management-The Orange Senqu River Basin in South Africa. Master's Thesis. University of Hamburg, Germany.

2. Makurira H, Mapani B, Mazvimavi D, Mul M, Magole L, et al. (2014) Transboundary water cooperation building partnerships (Part 2). Physics and Chemistry of the Earth, Parts A/B/C, 76: 1-2.

3. Ramollo P (2014) Lower Orange River forum-maintaining South Africa's largest river. Water Wheel 13: 40-41.
4. Malherbe W, Mahlangu S, Ferreira M, Wepener V (2015) Fish and macroinvertebrate community composition of a floodplain wetland associated with the Harts River, South Africa, in relation to water quality and habitat parameters. African Journal of Aquatic Science: 1-7.

5. Matthews S (2015) Orange River mouth-saving the integrity of one of SA's most important estuaries: water resource management. Water Wheel 14: 30-34.

6. Munyika S, Kongo V and Kimwaga R (2015) River health assessment using macroinvertebrates and water quality parameters: A case of the Orange River in Namibia. Physics and Chemistry of the Earth, Parts A/B/C. 76-78: 140-148.

7. ORASECOM-Orange-Senqu River Commission (2008) Orange-Senqu River Basin. Preliminary transboundary Diagnostic Analysis.

8. DWA-Department of Water Affairs, South Africa (2012) Development of Reconciliation Strategies for Large Bulk Water Supply Systems Orange River: Surface Water Hydrology and System Analysis Report. WRP Consulting Engineers Aurecon, Golder Associates Africa, and Zitholele Consulting. Report No: PRSA D000/00/18312/7.

9. DWA-Department of Water Affairs, South Africa (2012b) Inception Report for the Large Bulk Water Supply Systems of the Greater Bloemfontein Area. Prepared by Aurecon in association with GHT Consulting Scientists and ILISO Consulting as part of the Water Reconciliation Strategy Study for the Large Bulk Water Supply Systems: Greater Bloemfontein Area. DWA Report No: P WMA 14/C520/00/0910/01.

10. DWAF-Department of Water Affairs and Forestry, South Africa (2004) Interna Strategic Perspective: Orange River System Overarching. Prepared by PDNA WRP Consulting Engineers (Pty) Ltd, WMB and Kwezi-V3 on behalf of the Directorate: National Water Resource Planning. DWAF Report No: P RSA D000/00/0104

11. DWA-Department of Water Affairs. South Africa (2013c) National water resource strategy second edition: Water for an equitable and sustainable future. Pretoria: Department of Water Affairs, Republic of South Africa.

12. ORASECOM-Orange-Senqu River Commission (2011) Overall Project Executive Summary. Support to Phase 2 of the ORASECOM Basin-wide Integrated Water resources Management Plan. WRP Consulting Engineers in 
Citation: Mahasa Pululu S, Palamuleni Lobina G, Ruhiiga Tabukeli M (2015) The Upper Orange River Water Resources Affected by Human Interventions and Climate Change. Hydrol Current Res 6: 212. doi:10.4172/2157-7587.1000212

association with Golder Associates, DMM, PIK, RAMBOLL and WCE. Report number: ORASECOM 013/2011.

13. DEA-Department of Environmental Affairs, South Africa (2013) Long-Term Adaptation Scenarios Flagship Research Programme (LTAS) for South Africa. Climate Change Implications for Water Sector in South Africa. Pretoria. South Africa.

14. DWA-Department of Water Affairs, South Africa (2013b) Kalkfontein Scheme Operating Rule Establishment of Drought Operating Rules for Stand Alone Dams typical of Rural/Urban Municipal Water Supply Scheme (Central Region) Pretoria. WRP Consulting Engineers (Pty) Ltd. Report P RSA 000/00/14311/ Central/Kalkfontein.

15. DWA-Department of Water Affairs, South Africa (2013a) Development of Reconciliation Strategies for Large Bulk Water Supply Systems: Irrigation Demands and Water Conservation/Water Demand Management. Pretoria. WRP Consulting Engineers (Pty) Ltd., Aurecon, Golder Associates Africa, and Zitholele Consulting. Report P RSA D 000/00/18312/6.

16. DWA-Department of Water Affairs South Africa (2013d) Water allocation reform Portfolio committee on water and environmental affairs.

17. Viljoen MF, Armour RJ, Oberholzer JL, Grosskopf M, van der Merwe B, et al. (2006) Multi-dimensional Models for the Sustainable Management of Water Quantity and Quality with reference to the Orange-Vaal-Riet Convergence system. WRC Report No: 1352/1/06. Pretoria. Water Research Commission.

18. ORASECOM-Orange-Senqu River Commission (2009) Feasibility Study for the Development of a Mechanism to Mobilise Funds for Catchment Conservation. Conservation Fund Assessment Report - Identification of key mitigation measures. Report number: ORASECOM 003/2009.

19. DWA-Department of Water Affairs, South Africa (2011) Development of Reconciliation Strategies for all Towns in the Central Region. Lejweleputswa
District Municipality in the free State Province: Reconciliation Strategy for Brandfort Town Area consisting of Brandfort, Page Park, Majwemasweu, Mountain View and Somerset settlements in Masilonyana Local Municipality, in the Middle Vaal WMA. Pretoria. WRP Consulting Engineers (Pty) Ltd in association with DMM, Golder, KV3, Zitholele and Sub consultants. Contract WP 9713.

20. DWA-Department of Water Affairs, South Africa (2012c) Interim Reconciliation Strategy Report for the Large Bulk Water Supply Systems of the Greater Bloemfontein Area. Prepared by Aurecon in Association with GHT Consulting Scientists and ILISO Consulting as part of the Water Reconciliation Strategy Study for the Large Bulk Water Supply Systems: Greater Bloemfontein Area DWA Report No: P WMA 14/C520/00/0910/02

21. DWA-Department of Water Affairs, South Africa (2012d) Interventions Report for the Large Bulk Water Supply Systems of the Greater Bloemfontein Area. Prepared by Aurecon in association with GHT Consulting Scientists and ILISO Consulting as part of the Water Reconciliation Strategy Study for the Large Bulk Water Supply Systems: Greater Bloemfontein Area. DWA Report No. P WMA 14/C520/00/0910/03

22. DWA-Department of Water Affairs, South Africa (2012e) Reconciliation Strategy Report for the Large Bulk Water Supply Systems of the Greater Bloemfontein Area. Prepared by Aurecon in association with GHT Consulting Scientists and ILISO Consulting as part of the Water Reconciliation Strategy Study for the Large Bulk Water Supply Systems: Greater Bloemfontein Area.

23. DWA-Department of Water Affairs, South Africa (2012f) Water Quality Assessment Study for the Large Bulk Water Supply Systems of the Greater Bloemfontein Area. Prepared by Aurecon in association with GHT Consulting Scientists and ILISO Consulting as part of the Water Reconciliation Strategy Study for the Large Bulk Water Supply Systems: Greater Bloemfontein Area. 